\title{
ANALYSIS OF HISTORY MATERIALS OF TEACHING BOOK HISTORY OF \\ ISLAMIC CULTURE IN ISLAMIC SENIOR HIGH SCHOOL
}

\author{
Safari \\ UIN Raden Intan Lampung \\ safari@radenintan.ac.id
}

\begin{abstract}
Conceptually, Islam history with its special historiography characteristic has got scientific recognition that is not only in Islamic side. In the context of history of Islamic culture, it has implication relates to an effort for harmonizing between historical material with some lessons or morar value to become a basis for morality to then turn into the soft-skill development. Thus, several things relate to the exposure and the understanding of Islamic history at school, need to be stated in detail to become the subject for further research. The interesting thing to learn is the fulfillment of historical needs regarding chronological aspects and historical material testing according to some criteria that apply in historical research methodology. This research belongs to the category of library research. In this case, research data sources, both those directly or indirectly related to written material published in textbooks do not meet the standards of scientific work. The easiest indicator to see is the absence of footnotes, interpretations and looks only moving from the reference book.

again, this is related to the motive for the preparation of textbooks arrangements which are intended for purely educational purposes regardless to material validity to then turn to conclusion that the history textbook of Islamic culture is very difficult to be called as a history book, in the level of books and historical literature, it is in the tertiary position.
\end{abstract}

Keywords : Analysis, Islamic Senior High School, History of Islamic culture.

\section{INTRODUCTION}

based on Minister of Religion Regulation No.912 , 2013 concerning the 2013 Islamic school curriculum, subjects of Islamic religious education and Arabic, it was mentioned that there were five objectives in learning the history of Islamic culture in Islamic school aimed so that students have the following abilities. First, Building awareness of students about the importance of studying the basic in teaching, values and norms of Islam that have been built by the Prophet Muhammad in developing Islamic culture and civilization. Second, building students' awareness about the importance of time and place which is as a part of process in the past, present and future. Third, training the critical power of students to properly understand the facts of history based on a scientific foundation. Fourth, building appreciation of students for the legacy of Islamic history as the proof of Islamic civilization in the past. Fifth, developing ability of students to take lessons from Islam history, imitating outstanding figures and associating them with social, cultural, political, economic, science and technology phenomena, and others to develop Islamic 
culture and civilization. ${ }^{1}$ It must be

recognized that among all objectives, the third point that emphasizes scientificcritical education in looking at history for students, is the most neglected item in learning the history of Islamic culture today. one of the representative indicators is to pay attention to historical narratives in Islamic culture history text books, the majority of which accommodate all of the above objectives, except the third point. ${ }^{2}$ Conceptually, Islamic history with distinctive historiographic characteristics has gained scientific recognition that is not only in the Islamic world. Islamic history and world history have had a relationship from the beginning or Boaz Shoshan has called it as a unique relationship. ${ }^{3}$

\footnotetext{
${ }^{1}$ Kementerian Agama, Peraturan Menteri Agama No. 912 Tahun 2013 Tentang Kurikulum Madrasah Tahun 2013 Mata Pelajaran Pendidian Islam dan Bahasa
} Arab, (Jakarta: Kemenag, 2013) p. 52.

2 This is seen from the class of Core Competence which focuses more on aspects of morality and nurturing lesson, rather than building scientific attitudes towards the narrative of Islamic History.

${ }^{3}$ According to Boaz Shoshan, studying classical Islamic treasures such as the Tarikh at-Thabary has a tremendous influence at the internal and external levels. In the internal world of Islamic scholarship, atTabari's work is quite influential like the confession put forward by Ibn Mugallis (d. 324 H / 936 AD). It cannot be denied that his creativity has been widely enjoyed by Moslem scientists in the Middle Ages. The Fatimid rulers spent a hundred dinars to reproduce copies of the work and store it in a library of twenty copies. From other reports, according to Shosan, the Fatimiyyah palace library even kept at least 1,220 copies of the Tabari-Date. This shows the indicator of the popularity of Tabari at the time. In the West, the at-Tabari work has been known for several hundred years. In the Bibliothe'que Orientale by d'Herbelot (1625-1695 AD) it was mentioned at length that at-Tabari was a famous historian of its time. J. H. Mordtmann, an orientalist in the 19th century AD, even called it "Vater der Geschichte Arabischen." (Father of Arabic History).
Curriculum 13 basically has three

aspects of assessment, namely aspects of attitude, knowledge and skill aspects. ${ }^{4}$ in the context of the subjects of the history of Islamic culture, this has implications for an effort to harmonize historical material with lessons or value that can be taken from it to next become the basis of morality and turn to the development of soft skills. thus, several things related to the presentation and understanding of Islamic history at school, should be detailed and become the subject of further research.

an interesting thing to explore is the analysis of historical material in the textbook that includes several domains. among them the most important one is the fulfillment of historical needs regarding chronological aspects of history and historical material testing based on several criterias that apply in historical research methodology. historical explanation as mentioned by Kuntowijoyo is an effort to explain history so that it can be easily understood(intelligible). ${ }^{5}$

Theoretically, the subject matter of history

M. J. de Geoje, orientalist at the same time and is the chief editor of the Tarikh at-Tabari at E. J. Brill in the Arabic edition, praising the work as a masterpiece whose fame will never fade. For more details, see Boaz Shoshan, Poetics of Islamic historiography;

Deconstructing Tabari's History (Leiden: Brill, 2004), p. Xxvii.

${ }^{4}$ Exposure to the Deputy Minister of Education and Culture R.I for Education

field, "Konsep dan Implementasi Kurikulum 2013", p. 25.

${ }^{5}$ Kuntowijoyo, Penjelasan Sejarah (Historical

Explanation) (Yogyakarta: Tara Wacana, 2008), p.3-4 
at the school naturally meets several components. first, the existence of historical material in the explanation of space and time has relation relates to cause and effect. Second, as explained by Aman, that historical learning material must show synchronous indicators and meaning of events that are contextual and presented with pleasant material. ${ }^{6}$ In diakronic context, speak more straightly in terms of time and lengthen in terms of time and little or narrow in space. this should be distinguished from the social sciences which discuss symptoms in space but with limited time.

This research revolves around examining historical material in Islamic senior high school of Islamic history textbooks which have been compiled in the context of curriculum 2013 from which the aspects of morality, skills and knowledge are positioned equally on the basic design of the building. This exploration covers several things; tracing historical sources, testing chronological aspects, and finding tendencies and paradigms that underlie historical material in textbooks on the history of Islamic culture in Islamic senior High school.

This study aims to examine the sources that are used as the basic topic in the arrangement of historical material in a textbook on Islamic cultural history for

\footnotetext{
${ }^{6}$ Ibid, p.136
}

Islamic senior High school. Other than it was also trying to find Islamic historical concepts taught in the Islamic senior high school on the basis of chronological historical laws and the observation of the constructs and tendencies in them.

\section{Theoretical Background}

This research departs from a clear dichotomy between history on the one hand and historical education on the other. This history is interpreted as a fact or event that happened in the past or rather a report and documentation related to an event in the past. By nature, it is a rigorous inquiry into the past phenomenon. while history education itself is understood as the most powerful media in introducing the past to students so they know the impact caused by past events in the period after and also in the present. ${ }^{7}$ One of the main domains in both is hisoriography or historical writing which must be taken seriously.

A historical narrative contained in a text requires an interpretation. Ibn Khaldun $^{8}$ has mentioned the existence of integrated aspects in the discipline of history (fann at-tarikh), namely aspects of birth (fi zahiriha) and inner aspects (fi Inneriha). In outward aspects, history is

\footnotetext{
${ }^{7}$ Kurniawati, "Pendidikan Sejarah dalam Kurikulum di Republik Federal Jerman: A Lesson Learned", Jurnal Pendidikan Sejarah, vol. 4, no. 1 (2014), p. 4.

${ }^{8}$ Ibn Khaldun, al-Muqaddimah, (Beirut: Dar al-Kutub al'Ilmiyyah, 2006), p. 3.
} 
nothing more than informations about days, countries, and things that happened in the past centuries. The story are wider and became the talk of each group in celebrations. As for the inner aspects, history is a review and assessment and analysis of various events and elements contained in them. In addition, it is also a deep knowledge of various events and their causality.

Furthermore, Franz Rosenthal says that the historiographical aspects of research are basically tracing the frame of mind built by a historian. ${ }^{9}$ The aspect of thinking itself is part of historical facts that needs to be explored in the context of historiography. Historical facts, as reported by Sartono Kartodirjo, recognize three distinctions, namely artifact (objects), socifact (social relations), and mentifact (mental). ${ }^{10}$

To find the "inventor of creation" of historical material, some other theoretical explanations are needed to dissect it, including hermeneutics. Since Wilhelm Dilthey divided knowledge into two, Naturwissenchaften (Natural Sciences) and Geisteswissenschaften (Humanities Sciences), history is categorized as a humanities science that makes hermeneutics a suitable approach to use

\footnotetext{
${ }^{9}$ Rosenthal, A History, h. 3.

${ }^{10}$ Sartono Kartodirdjo, "Sejarah Intelektual" dalam Sejarah Intelektual, ed. Leo Agung (Yogyakarta: Ombak, 2013), p. 208.
}

it. It is used to understand an inner context of the actions expressed in the words of the perpetrator. ${ }^{11}$

As quoted by Kuntowijoyo, Dilthey himself gave an example of how to interpret Plato's dialogue which incidentally is a written document with two main steps. First, put the dialog with the inner context. This is intended to find out the hidden background. Second, make interpretations of his words in order to know political tendencies, strengths and weaknesses. ${ }^{12}$

The hermeneutic approach applied in the study of humanities has a very close relationship with the concept of verstehen or "understanding" (understanding). In this case, both history and Geisteswissenschaften, both rely on the same method, namely verstehen. It is an attempt to put oneself in others by doing appreciation of values, and emotional meaning. He tried to dismantle the structure behind paper, ink, stone, and all man-made cultural goods. In turn, it also relates to the meaning that is in and the subjectivity of the perpetrator of history. ${ }^{13}$

Thus, the hermeneutical situation is one of the main contributors who helped building the construction of an author's understanding. The important thing to underline from Gadamer's idea is related to

\footnotetext{
${ }^{11}$ Kuntowijoyo, Penjelasan Sejarah, p. 3-4.

12 Ibid., p., 4.

${ }^{13}$ Ibid., 3-4.
} 
the existence of historical influences that overshadow an author. Knowledge and historical effects are two things that cannot be separated. ${ }^{14}$ In addition, he also said that awareness of "hermeneutical situations" is the key to know reality. Thus, hermeneutics is a tool for reading reality so that alienation does not occur. Gadamer said that the emergence of hermeneutics was based on an experience of two kinds of alienation of humans, namely the alienation of aesthetic consciousness and alienation of the historical consciousness. ${ }^{15}$

Related to this, a historical work is indeed very intertwined from a factor of historians' awareness and the surrounding reality. This situation is very possible to know by using an intellectual history approach. According to Sartono Kartodirdjo, the problem of consciousness is very important as a driving factor or creator of other historical facts, for example, revolution, war, rebellion, movement, and so forth. Viewed with that perspective, it is very essential to study mentifact in all its forms, especially its development which is the object of the study of mental history, intellectuals, or ideas. ${ }^{16}$

\footnotetext{
${ }^{14}$ Hans George Gadamer, Truth and Method, terj. Joel Weinsheimer and Donald G. Marshall (London: Contium, 1989), p. 336.

${ }^{15}$ Hans George Gadamer, Philosophical Hermeneutics, terj. David E. Linge (University of California Press, 2008), p. 4.

16 Kartodirdjo, "Sejarah Intelektual”, p. 208.
}

Sartono further said that intellectual history responds more to the dialectic between ideology and appreciation by its adherents. The elemets are on social forces; what creates tension between ideology and practice? This means that in Sartono's eyes, it is necessary to trace the relationship between idea formation and sociological factors. 17 Related to this, a history of thought will not be separated from the situation of the text or study of the text, the historical context and the relationship of the text to the situation of the community at that time. ${ }^{18}$

Related to this, E. Ladewig Petersen discusses the relevance of the origin of Islamic history writing to the political, social and religious situation, politic, social and religion. ${ }^{19}$ In short, the discussion that Petersen built was related to the historiographic relationship variables with the political interests of the ruler such as the emergence of court historians, historical flows adhered to by historians or historical links with ideology, or historical schools built by historians. Kohlberg also said that historical writing also has a connection with historical ideology, the attitude of a school towards historical actors, their justification of

\footnotetext{
${ }^{17}$ Ibid., p. 211-212.

18 Kuntowojoyo, "Sejarah Pemikiran", dalam Sejarah Intelektual, ed. Leo Agung, p. 217.

19 E. Ladewig Petersen, Ali and Muawiyah in Early Arabic Tradition: Studies on the Genesis and Growth of Islamic Historical Writing until the End of the Ninth Century (Copenhagen: Munksgaard, 1964), p. 83-118.
} 
figures who are in line with their flow, the location of different views of a school with other schools of events and figures is another side of historiography with historical ideology. 20

Basically, historians also built a vision of their time. Historical debates as objective knowledge will not be a problem when the history of basing sources outside of human thought such as buildings, currencies, graves, jars and relics of other objects can precisely be measured quantitatively. Historical sources originating from human testimonies can be said to be merely symbolic, historical facts which exist only in the mind of observation or the thoughts of historians will be subjective. ${ }^{21}$ In the battle of philosophical understanding of naturalism between positivism and idealism, the position of historians is in the second, namely the side of historical subjectivity. A lot of historians gets in the idealistic portion, wanting a history to occur in accordance with an idealization. In this case the subjectivity of historiography occurred.

This subjectivity simply illustrates that historical rationality is not like a positivistic concept that can be measured clearly, historical rationality can more accurately be said to be a building of

\footnotetext{
${ }^{20}$ Etan Kohlberg, The Attitude of the Imami-Shi'is to the Companion of the Prophet (Inggris: Oxford, 1971), p. 143-175.

${ }^{21}$ Poespoprodjo, Subjektivitas dalam Historiografi (Bandung: Remadja Karya, 1987), p. 15-16.
}

historian arguments in building the historical material he wrote. G. W. F. Hegel calls this the historical ratio. Hegel divides the historical methodology category into three things: (1) original history (original history); (2) reflective history and; (3) philosophical history. ${ }^{22}$ The original history meant by Hegel as history written based on actions, events and circumstances of society encountered by historical writers. $^{23}$ Reflective history that is intended by Hegel as a historical writing whose way of presentation is not limited by time relating to historians but whose spirit is beyond the present ${ }^{24}$. As for philosophical history, it relates ratio as the spirit of history. According to Hegel, the meaning of history is not only concerned with certain nations or certain social layers but concerns everyone who exists, has ever existed, and will exist without exception. ${ }^{25}$

In this sub explained the theoretical basis which includes an exposure related to historical material that is ideal for students who fulfill historical rules on the one hand and moral implications on the other. In addition to historical material, also reviewed in this chapter aspects of historical education. Some of the rules in history in turn are the

\footnotetext{
${ }^{22}$ G. W. F. Hegel, Introduction to The Philosophy of History (Indianapolis: Hackett Publishing, 1988), p. 3. ${ }^{23}$ Ibid.

${ }^{24}$ Ibid., 6.

${ }^{25}$ R. Z. Leirissa, "Pengantar" dalam Francis Fukuyama, The End of History and The Last Man, Kemenangan Kapitalisme dan Demokrasi Liberal, terj. M. Amrullah (Yogyakarta: Qalam, 2004) xii.
} 
basis for the seek of historical material that

is considered ideal to learn.

\section{Definition and Scope of Islamic Historiography}

As a starting point for the study of textbooks on the History of Islamic culture in Islamic Senior High School, one of the issues that is relevant to be described as a theoretical foundation is Islamic Historiography, considering that the textbook is also one of the documents describing Islamic history material and information for later learning by students in upper middle education units.

Historiography means historical writing or he speaks of the history of historical writing. The aspects studied are related to intrinsic and extrinsinsic elements of historical writing. Writing history itself is a working paper that requires a high imagination in the framework of reconstructing the past and requires the process of testing documents and the accuracy of the analysis of such delays $^{26}$. The assessment of historical writings of the past keeps a number of important references about the event. In this case, "historiography is the science of committing ideas and their causes to writing with reference to the time of their occurrence." 27 It can also be said that historiography is a history of historical

\footnotetext{
${ }^{26}$ Louis Gottschalk, Understanding History: A Primer of Historical Method (New York:Alfred A.Konpf,1964) p. 48

${ }^{27}$ Nisar Ahmed Faruqi, Early Muslim Historiography (Delhi: Idarah Adabita Delhi, 1976) p.2
}

writing that contains an analysis of the excess.

\section{Critical Traditions in Islamic Historiography}

In Islamic Historiography discourse, a historical narrative contained in a text requires an interpretation. This has led to a critical flow in Islamic history. Ibn Khaldun ${ }^{28}$ such as, it has mentioned the existence of integrated aspects in the historical discipline (fann at-tarikh), namely the aspect of birth (fi zahiriha) and inner aspects (fi Inneriha). In the outward aspect, history is nothing more than news about days, countries, and things that happened in the past centuries. The story widened and became the talk of each group in celebrations. As for the inner aspects, history is a review and assessment and analysis of various events and elements contained in them. In addition, it is also a deep knowledge of various events and their causality.

\section{Three of Islamic Lewis Version of}

\section{Islamic Hitsoriography}

$$
\text { Three Islamic historical }
$$

classifications of Bernard Lewis' version of also become a very relevant theoretical foundation in the study of historical material in this high school Islamic history book.

\footnotetext{
${ }^{28}$ Ibn Khaldun, al-Muqaddimah, 3.
} 
. First, the history that is remembered is in the form of history compiled based on the personal collection claimed to have originated from the past. Second, recovered history, namely in the form of history that was once buried and forgotten - then revealed again. Third, history I invented in the form of history created for certain purposes. $^{29}$

Some of the above explanations are the main theoretical measures in this study.

First, remembered history, this type of history revolves more around statements about the past, rather than history in a strict sense. This type of history is compiled based on personal collections claimed to have originated from past generations to living traditions. For example, as seen in manuscripts, classical literary works, and historiography of the past. In many ways, this kind of history might be described as the collective memory of a community or nation or other entity. What was chosen to be remembered, both through the work of leaders, rulers, poets, and storytellers, is what is considered meaningful as reality and symbols.

Second, recovered history. This is the history of events and movements, figures and ideas, which in a certain extent have been forgotten and with certain

29 Bernard Lewis, Sejarah, Diingat, Ditemukan Kembali, Ditemu-Ciptakan, terj. Bambang A. Widiyanto (Yogyakarta: Ombak, 2009), 11-12. reasons rejected by the collective memory of a community. Then, after a long or short period of time, he was rediscovered by experts through the study of historiographic records, archaeological excavations of lost and buried cities, interpretation and breakdown of forgotten texts and languages and forgotten past reconstruction. Third, invented history. This is history written with a purpose, more precisely a new goal, which is different from the previous goals. It is a history that is extracted and interpreted from the two types of history above if possible and engineered if it's not. ${ }^{30}$.

Research on historical material in textbooks on the history of Islamic culture in Islamic high school has relevance to historical concepts that are invented (invented history). To find the historical "inventor", some other theoretical explanations are needed to dissect this, including hermeneutics, historical pragmatism, and historiography subjectivity.

\section{RESEARCH METHODOLOGY}

This research belongs to the category of library research. In this case, research data sources, whether directly or indirectly related, come from written materials that are published in the form of books, journals, and others. The data sources are divided into two categories, 
primary data sources and secondary data sources.

The primary source used in this study is a textbook on the history of Islamic culture in Madrasah Aliyah which was officially published by the Ministry of Religion. In addition, a comparison with the works of modern historians from Islam or the West will also be used as a comparison as well as analysis tools for historical material in the islamic high school.

The data processing method used in this study is descriptive-analytic, namely research in the form of describing, recording, analyzing, and interpreting the things to be studied. In more detail, this study also uses the historical research method which includes four stages; (1) Heuristics, namely collecting as many as possible several data sources that are relevant for research, in this case the study of historical material in the book teaching the History of Islamic culture in Islamic high school. (2) Criticism of sources, namely efforts to assess, test, and select sources that have been collected, (3) Interpretation, namely the process of interpreting historical data that has been found through source criticism,

Historiography / historical writing, namely data presentation collected.

In this case, the interpretation of the text of the history textbook is carried out using a hermeneutic approach, especially in the context of the hermeneutic of the objectivist school. ${ }^{31}$ The use of hermeneutics, in seeing this work, is interpreted as follows: First, the text contained in the book is treated as a talking fruit, which has its own world, anachronism is avoided as much as possible, ${ }^{32}$

in the sense that the author tries to get involved to the world of the work. In this case the understanding of humanity (humanistic understanding) is very necessary. ${ }^{33}$ Second, the thing that is the pressure point is the appreciation of the

31 Menurut Sahiron Syamsuddin, terdapat tiga aliran hermeneutika: Pertama, obyektivis, aliran ini menjadikan pencarian makna asal dari sebuah obyek penafsiran (teks tertulis, ucapan, perilaku, simbol, dan sebagainya) sebagai titik aksentuasi. Dalam perspektif ini, penafsiran adalah merekonstruksi apa yang dimaksud oleh pencipta obyek/teks. Di antara eksponen aliran obyektivis adalah Friedrich Schleiermacher dan Wilhelm Dilthey. Kedua, subyektivis, aliran ini menekankan terhadap peran pembaca/penafsir dalam pemaknaan terhadap teks. Ia membawa teks secara lebih independen dari pengarangnya. Aliran ini secara umum merepresentasikan hermeneutika post-modern, sejak masa strukturalisme, post-strukturalisme dan dekonstruksionisme. Menurut aliran ini, teks bersifat otonom atau berdiri sendiri dan tidak mutlak bergantung pada intensi pengarang. Di antara eksponen aliran ini adalah Jaques Derrida dan Dany J. Anderson. Ketiga obyektivis cum subyektivis, aliran ini berada di tengah-tengah antara dua aliran di atas. Ia memberikan keseimbangan antara pencarian makna asal teks dan peran pembaca dalam penafsiran. Di antara eksponen aliran ini adalah Hans George Gadamer dan Jurgen Gracia. Sahiron Syamsuddin, Hermeneutika dan Pengembangan Ulumul Qur'an (Yogyakarta: Nawesea Press, 2009), 26-41.

32 Pembacaan anakronistik menurut Robinson merupakan sesuatu yang tidak sepatutnya diterapkan dalam membaca otoritas Islam awal yang sebenarnya menunjukkan sesuatu aktivitas yang dinamis. Menurutnya hal tersebut akan mengarah kepada ketidakadilan dalam menempatkan sejarah masa lalu. Robinson, Islamic Historiography, 54.

33 Richard E. Palmer, Hermeneutics: Interpretation Theory in Schleirmacher, Dilthey, Heidegger, and Gadamer (Evanston: Northwestern University Press, 1969) 7. 
historical meanings that want to be tracked and studied. According to Machasin, that time and place need to be explained to get meaning and understanding that are clear and relevant to the present. ${ }^{34}$

Thus, there is a need for philosophical elaboration in understanding what exists between times and texts, understanding clearly the revolutions of meaning throughout history. In Ferguson's language, this was aimed at overcoming the gap between the past and the present (to span the gap between the past and present). ${ }^{35}$

\section{RESULTS AND DISCUSSION}

\section{Teaching book, Text book, Textbook}

Ministry of Research, Technology

and Higher Education has established several criterias related to the preparation of teaching materials. "teaching book" is a book that aims as teaching material, so it is called as teaching book, or teaching materials or even books (materials) taught. It functions to help teachers and students in learning. The existence of written teaching materials, makes the teacher do not need to present too much material in class. The teacher will have more time to provide guidance to students.

For students, textbooks can increase their excitement (because they don't keep listening to the teacher's lectures, and can

\footnotetext{
${ }^{34}$ Machasin, "Sumbangan Hermeneutika Terhadap Ilmu Tafsir", Makalah dipresentasikan pada acara Diskusi Dosen Tetap UIN Sunan Kalijaga, 2002, 63.

${ }^{35}$ Duncan S. Ferguson, Biblical Hermeneutic: An Introduction (London: SCM Press, 1969), 3
}

learn actively independently) and are also able to enrich the information they receive. Teaching materials contain systematically arranged learning material used by teachers and students in the learning process.

Textbooks are different from textbooks. The difference is not only in the format, layout and appearance, but especially in the orientation and approach used in the preparation.

Teaching books are different from textbooks. The difference is not only in the format, layout and appearance, but especially in the orientation and approach used in the preparation. ${ }^{36}$

The following table presents differences (the presentation of these differences is very extreme, in fact not so, of course there are teaching books that are almost like text books, and vice versa) between teaching book and text books. ${ }^{37}$

\begin{tabular}{|l|l|}
\hline Teaching Book & Text book \\
\hline 1. Written and & 1.Written for a wider \\
designed to be & audience. \\
used by students & \\
(especially & \\
students who gets & \\
involved the & \\
learning) & \\
\hline
\end{tabular}

36 Suhardjono, "Menyusun Buku Ajar", Makalah Pendukung pada Pelatihan Penulisan Bahan Ajar Peningkatan Kompetensi Pendidik PAUD dan PNF, Jakarta, Kemendikbud, 08 Januari 2012, .

${ }^{37}$ Ibid., 


\begin{tabular}{|c|c|}
\hline $\begin{array}{l}\text { 2. Used in a limited } \\
\text { scope. designed for } \\
\text { use in instructional } \\
\text { activities }\end{array}$ & $\begin{array}{l}\text { 2. Designed to be } \\
\text { disseminated widely. } \\
\text { used in general }\end{array}$ \\
\hline $\begin{array}{l}\text { 3. Explaining } \\
\text { instructional goals } \\
\text { (explain } \\
\text { competencies to be } \\
\text { achieved) }\end{array}$ & $\begin{array}{l}\text { 3. Not necessarily } \\
\text { explaining } \\
\text { instructional goals }\end{array}$ \\
\hline $\begin{array}{l}\text { 4. The structure is } \\
\text { based on student } \\
\text { needs and } \\
\text { competencies } \\
\text { students will } \\
\text { achieve, }\end{array}$ & $\begin{array}{l}\text { 4. The structure is } \\
\text { based on the logic of } \\
\text { the field of science }\end{array}$ \\
\hline $\begin{array}{l}\text { 5. Provide } \\
\text { opportunities for } \\
\text { students to } \\
\text { practice }\end{array}$ & $\begin{array}{l}\text { 5. Generally it does } \\
\text { not give the reader } \\
\text { the chance to } \\
\text { practice }\end{array}$ \\
\hline 6. Give summary & $\begin{array}{l}\text { 6. Not necessarily } \\
\text { give summary. }\end{array}$ \\
\hline $\begin{array}{l}\text { 7.Content } \\
\text { completeness } \\
\text { based on student } \\
\text { needs }\end{array}$ & 7. Too complete \\
\hline $\begin{array}{l}\text { 8. Generally } \\
\text { provide an } \\
\text { explanation of how } \\
\text { to study teaching } \\
\text { materials }\end{array}$ & $\begin{array}{l}\text { 8. Generaallydoes not } \\
\text { provide an } \\
\text { explanation of how to } \\
\text { study teaching } \\
\text { materials. }\end{array}$ \\
\hline
\end{tabular}

Paulina, as quoted by Suhardjono, stated that there are at least three ways that teachers can use in preparing teaching materials, namely :38
a) self-writing
b) remaking information, and
c) realignment.

In the practice of writing teaching book, the teacher performs by combining the three methods. In accordance with the instructional objectives, the teacher collects various information from various sources, both from text books, scientific articles, journals, news in the mass media, and so on. The information is then collected according to the needs of the students. Furthermore, by using a systematic framework structure the information is organized, collected and written as a teaching book (material). ${ }^{39}$

Besides the two types of books, there are also known Textbooks. Textbooks are books containing knowledge for certain fields of science or subjects and are intended for students at certain levels of education. The book is generally written by a teacher or group of teachers, intended to assist students in understanding certain subjects, or as a teacher's teaching materials, both main and complementary grips. ${ }^{40}$

generally the framework of the textbook content is as follows:

\footnotetext{
38 Ibid.,

${ }^{39}$ Ibid,p.

${ }^{40}$ Ibid,p.
} 
a) Preface

\section{b) Introduction}

1) Table of contents

2) Purpose of the textbook

\section{c) Content Section}

1) Title of the chapter or topic of discussion

2) Explanation of the purpose of the chapter

3) Description of the contents of the lesson

4) Explanation of theory

5) Sample presentation

6) Practice questions

\section{d) Support Section}

1) literature Review

2) Biography

As a matter of fact, the preparation of this book also relates to an era with credit numbers in the development of the teaching profession. The physical evidence of the book that must be included in the submission of credit numbers is in the form of an original book or photocopy that clearly shows the author's name or the name. The book must also clearly indicate the name of the publisher, the year of publication, as well as other necessary information such as (if any) approval from National Education Standards Agency

, International Standard Book Number and others. ${ }^{41}$

41 Ibid.,
In the context of this research, even though the term used is "Teaching book" or "Student Book", the format of this book actually falls into the category of teaching book in the framework of the above definition. The primary source in this study is the teaching book on Islamic Culture History published by the Ministry of Religion in 2014, the first edition. This restriction needs to be done considering the existence of teaching books The history of Islamic culture and other religious subjects is indeed varied and is constantly revised from time to time. This is reflected in the disclaimer found at the beginning of the teaching book that says: ${ }^{42}$

"This Student Book was prepared by the Government in the framework of implementing the 2013 Curriculum. This book was compiled and reviewed by various parties under the coordination of the Ministry of Religion, and was used in the application of the 2013 Curriculum. changing times. Feedback from various groups is expected to improve the quality of this book."

It is compiled as other teaching books, it is written collectively by several contributors

42 Kementerian Agama, Buku Siswa; Sejarah Kebudayaan Islam (Jakarta: Kementerian Agama, 2014), p. ii. 
in their respective sections, including contributors to texts and script reviewers. The content of this book follows the format adapted to the 2013 Kurikuum as follows:
a) Cover

\section{b) Front page}
c) Preface
d) Transilteration Guidelines
e) Instructions for Using Books
f) Explanation Core Competence and Basic Competence

\section{g) Table of Contents}

\section{h) Material}

\section{i) References}

The instructions for using this book are designed to be very practical and fun, because there are easy illustrations and instructive instructions for the course of learning History Islamic culture. The following is an example of an illustration in the Class X Islamic High School teaching book for the discussion of the Civilization of the Arabs Before the Arrival of Islam.

Content of historical material in textbooks as well as general also has narrative characteristics without regard to citation. Historical material is narrated in the form of stories which in several places are affixed to the content of theological material morality.
In the academic context, the

format for preparing historical material in textbooks does not meet the standards of scientific work. The easiest indicator to see is the absence of footnotes, interpretations, and impressions of only moving from the reference book. Again, this is related to the motive for the preparation of teaching books that are intended for purely educational purposes without regard to material validity. This in turn leads to the conclusion that the textbook History of Islamic culture is very difficult to say as a history book, in the level of books and historical literature, it is in a "tertiary" position.

\section{REFERENCES}

Bernard Lewis, (2009) Sejarah, Diingat, Ditemukan Kembali, DitemuCiptakan, terj. Bambang A. Widiyanto, Yogyakarta: Ombak.

Boaz Shoshan, (2004) Poetics of Islamic Historiography; Deconstructing Tabari's History, Leiden: Brill.

Duncan S. Ferguson, (1969) Biblical Hermeneutic: An Introduction, London: SCM Press.

E. Ladewig Petersen, (1964) Ali and Muawiyah in Early Arabic Tradition: Studies on the Genesis and Growth of Islamic Historical Writing until the End of the Ninth Century, Copenhagen: Munksgaard. 
Etan Kohlberg, (1971) The Attitude of the Imami-Shi'is to the Companion of the Prophet, Inggris: Oxford.

G. W. F. Hegel, (1988) Introduction to The Philosophy of History, Indianapolis: Hackett Publishing.

Hans George Gadamer, (1989) Truth and Method, terj. Joel Weinsheimer and Donald G. Marshall London: Contium.

Hans George Gadamer, (2008) Philosophical Hermeneutics, terj. David E. Linge University of California Press.

Ibn Khaldun, (2006) al-Muqaddimah,

Beirut: Dar al-Kutub al-'Ilmiyyah.

Kementerian Agama, (2014) Buku Siswa;

Sejarah Kebudayaan Islam, Jakarta:

Kementerian Agama.

Peraturan Menteri Agama

No. 912 Tahun 2013 Tentang

Kurikulum Madrasah Tahun 2013

Mata Pelajaran Pendidian Islam dan

Bahasa Arab, Jakarta: Kemenag.

Kuntowijoyo, (2008) Penjelasan Sejarah

(Historical Explanation) Yogyakarta:

Tara Wacana,

"Sejarah Pemikiran", dalam

Sejarah Intelektual, ed. Leo Agung

Kurniawati, (2014) "Pendidikan Sejarah

dalam Kurikulum di Republik

Federal Jerman: A Lesson Learned", Jurnal Pendidikan Sejarah, vol. 4, no. 1
Louis Gottschalk, (1964) Understanding History: A Primer of Historical Method, New York:Alfred A.Konpf.

Machasin, (2002) "Sumbangan Hermeneutika Terhadap Ilmu Tafsir", Makalah dipresentasikan pada acara Diskusi Dosen Tetap UIN Sunan Kalijaga.

Nisar Ahmed Faruqi, (1976) Early Muslim Historiography Delhi: Idarah Adabita Delhi.

Paparan Wakil Menteri Pendidikan dan Kebudayaan R.I Bidang Pendidikan, "Konsep dan Implementasi Kurikulum 2013".

Poespoprodjo, (1987) Subjektivitas dalam Historiografi, Bandung: Remadja Karya.

R. Z. Leirissa, (2004) "Pengantar" dalam Francis Fukuyama, The End of History and The Last Man, Kemenangan Kapitalisme dan Demokrasi Liberal, terj. M. Amrullah, Yogyakarta: Qalam.

Richard E. Palmer, (1969) Hermeneutics: Interpretation Theory in Schleirmacher, Dilthey, Heidegger, and Gadamer, Evanston: Northwestern University Press.

Sahiron Syamsuddin, 2009 Hermeneutika dan Pengembangan Ulumul Qur'an, Yogyakarta: Nawesea Press.

Sartono Kartodirdjo, (2013) "Sejarah Intelektual" dalam Sejarah 
Intelektual, ed. Leo Agung Yogyakarta: Ombak.

Suhardjono, (2012) "Menyusun Buku Ajar", Makalah Pendukung pada Pelatihan
Penulisan Bahan Ajar Peningkatan Kompetensi Pendidik PAUD dan PNF, Jakarta, Kemendikbud. 